\title{
Burning Questions of Treating Addiction in Middle Europe - The German situation
}

\author{
Tamás Józsa (10) \\ Pedagogical Assistance Service of Budapest, Institution of the 22 ${ }^{\text {nd }}$ District; University of Debrecen, Human Sciences PhD School, \\ Psychology Program, Budapest, Hungary
}

ORCID ID of the author: T.J. 0000-0002-3858-4094.

Cite this article as: Józsa T. Burning Questions of Treating Addiction in Middle Europe - The German situation. Cyprus J Med Sci 2020; 5(I): 99-100.

The World Health Organization has delayed time and time again on publishing any conclusive data on video game addiction (VGA). This could be because they have not yet acquired sufficient scientific data about VGA from the whole of the European Union (UN) to verify its significance in public health. In the United States, spending too much time playing video games was classified as an addiction by the American Psychiatric Association in 20I3 (I). In the Far East, a type of mental disorder, termed "hikikomori," was first described at the beginning of the century, where electronics effectively replace all social function. Specifically, it describes the phenomenon of teenagers and young adults substituting their interpersonal relationships with electronic devices and living in total social isolation (2). It is time for European decision makers to take a stand and announce that they will not wait any longer to emphasize this issue because VGA will officially be included in the international classification of diseases from 2022 (3).

Regarding many new psychological diagnoses, initially there was a pushback from the public toward the VGA diagnosis in early stages. However, as smart devices became more ingrained in our everyday life, the time spent on them has exponentially increased. Some experts believed that it was a growing problem when just PCs and and video game consoles were the primary source; however, with the advent of smart devices, there seems to be no end to the number of games and apps available. Virtually everyone, child, adolescent, and adult, owns a smart device-even those from economically challenged countries. Additionally, outsiders have little to no influence on what others do on their smart device. Identifying where useful or relaxing activities end and harmful, socially crippling activities begin is not easy. American researchers have demonstrated that an astounding $99 \%$ of boys and $94 \%$ of girls, aged 2-17 years, regularly play video games. The numbers are also high for American adults, with $50 \%$ of men and $40 \%$ of women engaging in video game activity on a regular basis (4). A recent international daily news source reports that in the Far East, treatment camps for teenagers with electronic device addiction are being organized since 2007 (5). Studies in the EU show 5\%-6\% prevalence, but Austria and Germany are naturally at a greater risk owing to their technical and economic development (6). Interactive entertainment is a wildly successful international industry. In 2016, both China and North America topped the list of countries providing revenue to this burgeoning industry and Germany was the top country in the EU (7).

Behavioral addictions, such as VGA or gambling) and their financial factors have an economic significance. For instance, they can increase the number of absences from work, and this can impact the financial resources of the addict; this problem is not restricted to the United States; it is also noted in Austria and Germany (8). The ratio of German patients with VGA is $6 \%$ in pre-puberty and puberty (10-18 year olds) and $8 \%$ over the age of 18 (9). . However, these data do not include those at risk in the sub-clinical stage. Additionally, a study with 12,000 participants showed that $70 \%$ of subjects admit to lying about the time spent on gaming, highlighting an issue of self-administered questionnaires and their potential of including underestimated data (I0).

It is obvious that this phenomenon is a modern, globally spreading challenge of the 2lst century that we have to face. It is clear that we need to take action; prevention, early treatment, and improvements in educating medical personnel regarding these novel mental health issues are needed. In 2008, 99\% of German households had a mobile phone, $99 \%$ had a 
computer, and $96 \%$ had access to the internet (II). It is clear that electronic media will most likely continue to play a huge part in our lives and those of future generations.

Lastly, the growth of cyberbullying (an online form of harassment) is an important factor worldwide. A recent study showed that 600,000 of 12.3 million German students were victims of cyberbullying (12). In Germany, mostly classmates are bullies; however, this stays hidden from the teachers and others as a great part of bullying happens through electronic devices and video games; thus, extra attention is needed when it comes to electronic media usage (13). Another study in Germany shows that victims of cyberbullying have high rates of suicide and can be virtual outcasts online and many of the individuals have negative experiences with online communities (14). It is cardinal because being at risk of cyberbullying has a connection to time spent video gaming: as the level of addiction to virtual reality increases the negative feedback becomes more important and has a greater influence to children's self-representation.

The author is a Clinical Child Psychologist, Marriage and Family Therapist, PhD candidate at the University of Debrecen, Human Sciences PhD School, Psychology Program; currently works at the Pedagogical Assistance Service of Budapest, Institution of the 22nd District in Budapest.

Peer-review: Externally peer-reviewed.

Conflict of Interest: The author have no conflicts of interest to declare.

Financial Disclosure: The author declared that this study has received no financial support.

\section{REFERENCES}

I. Diagnostic and Statistical Manual of Mental Disorders (DSM-5) (2013). Washington DC: APA.
2. Masataka N. Low anger-aggression and anxiety-withdrawal characteristic to preschoolers in Japanese society where "hikikomori" is becoming a major social problem. Early Educ Dev 2002; 13(2): 187200. [CrossRef]

3. Available from: URL: https://www.shepherdshillacademy.org/resources/video-game-addiction-teens Downloaded: 2019.07.10.

4. Granic I, Lobel A, Engels RC. The benefits of playing video games. Am Psychol 2014; 69(I): 66. [CrossRef]

5. Available from: URL: https://www.bbc.co.uk/newsround/48855182 Downloaded: 2019.07.08.

6. Feng W, Ramo DE, Chan SR, Bourgeois JA. Internet gaming disorder: trends in prevalence 1998-2016. Addict Behav 2017; 75: 17-24. [CrossRef]

7. 2016 Global Games Market Report: An Overview of Trends and Insights (2016). Available from: URL: https://cdn2.hubspot.net/ hubfs/700740/Reports/Newzoo Free 2016 Global Games Market Report.pdf, Downloaded: 2019.06.0I.

8. Effertz T, Bischof A, Rumpf HJ, Meyer C, John U. The effect of online gambling on gambling problems and resulting economic health costs in Germany. Eur J Health Econ 2018; 19(7): 967-78. [CrossRef]

9. Jeromin F, Rief W, Barke A. Validation of the Internet Gaming Disorder Questionnaire in a sample of adult German-speaking internet gamers. Cyberpsychol Behav Soc Netw 2016; 19(7): 453-9. [CrossRef]

10. Rehbein F, Kliem S, Baier D Mößle T, Petry NM. Prevalence of Internet gaming disorder in German adolescents: Diagnostic contribution of the nine DSM- 5 criteria in a state-wide representative sample Addiction 2015; II0(5): 842-5I. [CrossRef]

II. Schultze-Krumbholz A, Scheithaver H. Social-behavioral correlates of cyberbullying in a German student sample. Z Psychol 2009; 217(4): 224-6. [CrossRef]

12. Riebel J, Jäger RS, Fischer UW. Cyberbullying in Germany-an exploration of prevalence, overlapping with real life bullying and coping strategies. Psychol Sci 2009; 5I(3): 298-314.

13. Festl R, Scharkow M, Quandt T. Peer influence, internet use and cyberbullying: A comparison of different context effects among German adolescents. J Child Media 2013; 7(4): 446-62. [CrossRef]

14. Rehbein F, Kleimann M, Mößle T. Prevalence and risk factors of video game dependency in adolescence: results of a German nationwide survey. Cyberpsychol Behav Soc Netw 2010; 13(3): 269-77. [CrossRef] 